\title{
Potency of Murraya koenigii Leaves as Anti-Cancer Mammary in 7,12 dimethylbenz $(\alpha)$ anthracene (DMBA) induced-Sprague Dawley Rats
}

\author{
Siti Aisyah ${ }^{1}$, Ekowati Handharyani ${ }^{2}$, Nurliani Bermawie ${ }^{3}$, and Agus Setiyono ${ }^{2 *}$ \\ ${ }^{1}$ Faculty of Veterinary Medicine, Syiah Kuala University. Banda Aceh Indonesia \\ ${ }^{2}$ Department of Clinic Reproduction and Pathology, Faculty of Veterinary Medicine, IPB University. Bogor Indonesia \\ ${ }^{3}$ Indonesian Spice and Medicinal Crops Research Institute (ISMCRI). Bogor Indonesia
}

\begin{abstract}
The purpose of the research was to study the potency of Murraya koenigii leaves extract to overcome the mammary tumor in Sprague Dawley rat. Thirty-five female rats were divided into seven groups: control (P1), tumor without therapy (P2), methotrexate group (P3), curative groups (P4 and P5) were given extract after the tumor was formed, and preventive groups (P6 and P7) were given extract before the tumor was formed with dose of 300 and $400 \mathrm{mg} / \mathrm{kg}$, respectively. The induction of mammary tumor in rats were carried out using 7,12 dimethylbenz( $\alpha$ ) anthracene (DMBA) subcutaneously. Bodyweight and tumor size were measured every week for 4 weeks. At the end of treatment, rats were euthanized and mammary glands were collected for histopathological examination. The result showed tumor size in P2 was significantly higher $(\mathrm{p}<0.05)$ than in other groups. On the other hand, tumor size in P4 and P6 were significantly smaller $(\mathrm{p}<0.05)$ compared to P5 and P7. Histopathological changes showed PMN cells, 1-3 layers of cuboid epithelial and solid collagen fibers proliferation in P2, while in P3 to P7 showed moderate collagen fibers proliferation. In conclusion, the administration of the extract at a dose of $300 \mathrm{mg} / \mathrm{kg}$ can decelerate tumor development in Sprague Dawley rat mammary gland.
\end{abstract}

Keywords: anti-cancer, DMBA, mammary tumor, Murraya koenigii, Sprague-Dawley.

\section{Introduction}

Mammary cancer is among cancers with relatively high prevalence in Indonesia. Based on basic health research data cancer prevalence in Indonesia is 1.4 out of 1000 , which means around 347,000 people [1]. Cancer case is not only found on human but also in pet animals. The incidence and prevalence of mammary cancer most commonly found in pet female cat and dog. Mammary cancer ratio is higher in cat (86\%) compared to dog (42\%) [2]. Conventional medication has a lot of side effects and expensive, which makes herbal medicine a preferable alternative.

The medicinal plant has medical value for containing secondary metabolite compounds (active components). According to [3], secondary metabolites are highly potential as anti-cancer medicine since cytotoxicity occurs directly on the cancer cell or tumor growth is modulated until eventually inhibited. Several secondary metabolites function as anti-cancer/tumor compounds are alkaloid, flavonoid, and phenol. All of these active metabolites were contained in curry leaves (Murraya koenigii).

Researches on the use of curry leaves extract to mammary cell have been conducted by several researchers in in-vitro experiments. [4] used MCF-7 and
MDA-MB-231 stem cells where a hydro-methanolic extract of curry leaves found to be able to lower proteasome activity of cancer stem cells but cannot lower the proteasome activity of the normal cell. [5] used stem cell MDA-MB-231 for initial streaning of curry leaves methanol extract as anti-cancer which inhibits the growth of mammary cancer. Not only mammary cancer, but curry leaves was also used by other researches for another type of cancer. [6] used colon cancer stem cell (HT-29), where alkaloid girinimbine from curry leaves can cause apoptosis to cancer cells without being cytotoxic to normal colon cells (CCD-18Co). Another research by [7] similarly stated that the alkaloid of curry leaves can cause apoptosis on cancer colon cells (DLD-1). Research on mammary cancer treatment used curry leaves in vivo is still limited and thus this study is important in providing information about mammary cancer treatment by herbal medicine. The objective of this research was to study the curative and preventive potency of curry leaves extract on Sprague Dawley rat.

* Corresponding author: agusetiyo@yahoo.com 


\section{Materials and Methods}

\subsection{Animal Ethical Committee Approval}

This research has been approved by the Ethical Committee of Veterinary Medicine Faculty, Institut Pertanian Bogor, under certificate No. 094/KEH/SKE/VIII/2018.

\subsection{Experimental materials}

Curry leaves were obtained from around Faculty of Veterinary Medicine, IPB Dramaga, Bogor. The leaves were dried, ground, and extracted by ethanol $70 \%$ (Pharmacy Laboratory, Faculty of Veterinary Medicine, IPB). Curry leaves extract was then thickened by rotary evaporator in $4^{\circ} \mathrm{C}$ with $50 \mathrm{rpm}$ speed until a thick extract was obtained. 7,12 dimetylbenz $(\alpha)$ anthracene (DMBA, sigma). Female Sprague Dawley rat 150-250 g were obtained from the Laboratory Animal Management Unit (Unit Pengelola Hewan Laboratorium-UPHL ) Faculty of Veterinary Medicine, IPB.

\subsection{Toxicity Test}

Curry leaves ethanol extract (CLEE) toxicity test used Brine Shrimp Lethality Test (BSLT) method, which was conducted in the Biopharma Research Center laboratory, Biofarmaka, Bogor under number No. 405.020/LPSB IPB/IX/18. The sample test was done by using Artemia saline leach shrimp larvae aged 24 hours. The toxic effect of the extract was identified by the percentage of larvae death measured by probit analysis (LC50).

\subsection{Research design}

Mammary cancer induction used DMBA $20 \mathrm{mg} / \mathrm{kg}$ body weight 2 times for 2 weeks. DMBA was diluted in olive oil and then injected into the rat $1 \mathrm{ml} /$ rat subcutaneously by the mammary gland.

Thirty-five female Sprague Dawley rats aged 3-4 months were divided into 7 groups. P1 group was the normal group (control). P2 group was the cancer control group, only given the placebo. P3 group was the control medicine group of methotrexate (MTX) $0,125 \mathrm{mg} / \mathrm{kg}$ given after cancer was formed. The curative group (P4 and P5) were given CLEE $300 \mathrm{mg} / \mathrm{kg}$ and $400 \mathrm{mg} / \mathrm{kg}$ after cancer was formed. Preventive group (P6 and P7) were given CLEE $300 \mathrm{mg} / \mathrm{kg}$ and $400 \mathrm{mg} / \mathrm{kg}$ along with DMBA injection before the tumor has formed. MTX and CLEE were given for 30 days.

Rats were weighed every week form the first week until the end of MTX and CLEE administration. Tumor palpation by the mammary gland was conducted after the last DMBA injection.

\subsection{Tumor size}

Tumor diameter was measured by digital calipers every week until treatment was done. Tumor volume estimation was based on [8].
$T=\frac{\left(a b^{2}\right)}{2}$

where; T: tumor volume, a: longest diameter, b: shortest diameter

\subsection{Histopathology examination}

By the end of treatment, the rat was euthanized and mammary tumors were fixated in neutral bufferedformalin (NBF) 10\%. Afterward, the samples were stained by haematoxylin eosin (H\&E).

\subsection{Data analysis}

Data obtained will be analyzed by ANOVA and if there are significant differences between parameters, Duncan test was conducted. Data was analyzed by SPSS program.

\section{Results and Discussion}

\subsection{Toxicity of Curry leaves Ethanol Extract}

The death of Artemia salina Leach is used as a parameter to show the presence of cytotoxic plant active compounds. CLEE toxicity test result with the BSLT method showed an $\mathrm{LC}_{50}$ value of $628.83 \mathrm{ppm}$. CLEE toxicity test on Wistar rat conducted by [9] reported that the administration of $500 \mathrm{mg} / \mathrm{kg}$ dosage for 28 days is safe and does not cause damage to organs. [10] used curry leaf methanol extract on albino Swiss mouse up to $9000 \mathrm{mg} / \mathrm{kg}$ dosage for 10 days without any toxic effect. Based on extract toxicity image by BSLT method and rat in vivo features, CLEE administration of 300 and $400 \mathrm{mg} / \mathrm{kg}$ dosage in this research are deemed safe for use.

\subsection{Curry leaves ethanol extract (CLEE) application on rat mammary cancer}

Every treatment group showed body weight increase every week as shown in Figure 1. DMBA induction and CLEE administration did not affect the rate of body weight increase since every treatment also experienced an increase in body weight similar to the normal control group. Bodyweight increase in rats given CLEE is not significantly different from the tumor control group and normal control group. [11] stated that curry leaves juice administration on albino Swiss mice for 15 days did not affect body weight increase. P3 group bodyweight fluctuated every week and tend to show a small increase. 


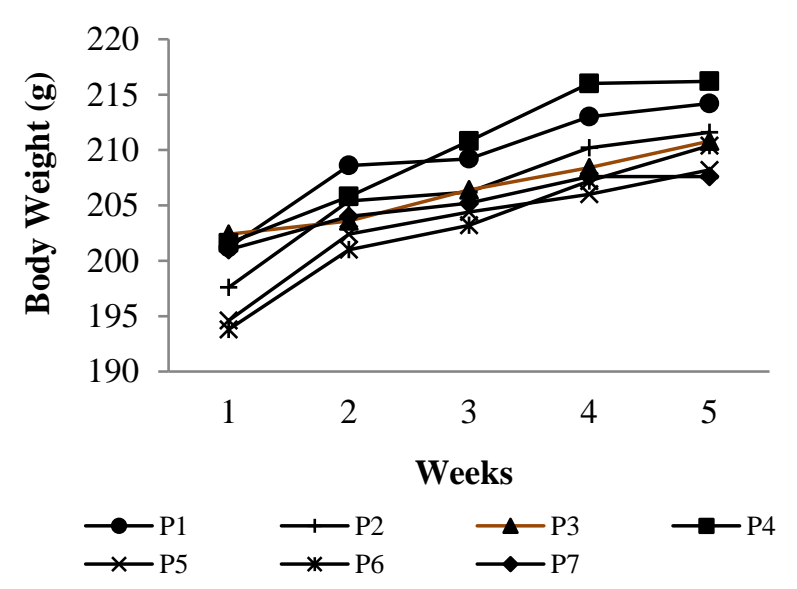

Figure 1. Rat body weight every week before and after DMBA induction. The value obtained is the average of $n=5$ per group. One-way ANOVA test on weight between groups showed insignificant differences $(\mathrm{p}<0.05)$.

Based on clinical examination, the rats appeared lethargic, with ruffled air, watery eyes and nose, and lowering appetite. This could be because long term administration of MTX appeared to be toxic. [12] stated that MTX administered for 28 days can lower appetite and body weight and is toxic.

Average tumor volume for every group can be seen in Table 1, where an increase appeared to occur every week as shown in Figure 2.

Table 1. Sprague Dawley rat tumor volume with curative and preventive extract administration

\begin{tabular}{cc}
\hline Groups & Tumor Volume $\left(\mathbf{m m}^{\mathbf{3}}\right)$ \\
\hline P1 & $0,00 \pm 0,00^{\mathrm{a}}$ \\
P2 & $704,42 \pm 659,17^{\mathrm{d}}$ \\
P3 & $177,40 \pm 118.82^{\mathrm{ab}}$ \\
P4 & $182,44 \pm 138,72^{\mathrm{ab}}$ \\
P5 & $559,73 \pm 466,12^{\mathrm{cd}}$ \\
P6 & $206,55 \pm 246,02^{\mathrm{ab}}$ \\
P7 & $323,65 \pm 316,56^{\mathrm{bc}}$ \\
\hline
\end{tabular}

Tumor volume increase on the $\mathrm{P} 2$ group is the fastest when compared with group P3, P4, P5, P6, and $\mathrm{P} 7$. Statistical analysis shows that $\mathrm{P} 2$ tumor volume is significantly different $(\mathrm{p}<0.05)$ with group P3, P4, P5, P6, and P7. Meanwhile, the tumor volume of P3, P4, and P6 are significantly lower $(\mathrm{p}<0.05)$ compared to group P5 and P7. The slowing growth of tumor volume in Group P3, P4, P5, P6, and P7 is probably caused by the therapy given to the groups, which were MTX administration and CLEE administration.

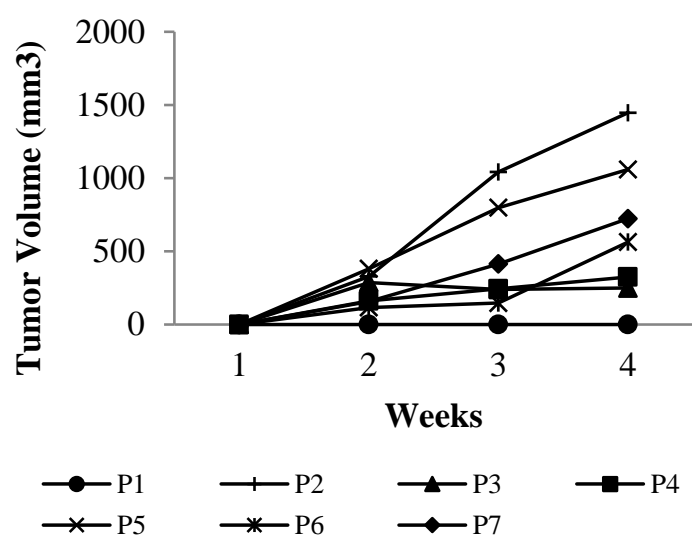

Figure 2. Rat tumor volume (mm3) every week after DMBA induction and administration of MTX and extract. One-way ANOVA test showed a significant difference between treatment groups $(\mathrm{p}<0.05)$.

Based on CLEE dosage used in curative and preventive stage, CLEE $300 \mathrm{mg} / \mathrm{kg}$ dose showed slower tumor volume growth compared to $400 \mathrm{mg} / \mathrm{kg}$ dosage, thus making it more effective as CLEE therapy. According to [13], Murraya keonigii extract treatment in albino Swiss mice inoculated with Dalton's Ascitic Lymphoma (DAL) cell by intraperitoneal route can lower tumor weight and prolong life span. [14] experimented by using nude mice induced with a mammary cancer cell (MDA-MB231) and given curry leaf extract, which was proven to lower tumor growth. Statistical analysis showed that P3, P4, and P6 groups are not significantly even though P3 showed smaller tumor volume. Thus, CLEE therapy (curative and preventive) can be used as an alternative therapy from MTX.

Histology image of the P1 group and the mammary gland histopathology of group P2 P3, P4, P5, P6, and P7 can be seen in Figure 3. P1 group microscopic image showed mammary gland epithelial cells in onelayer cuboid shape surrounded by fibroblast cells and adipose cells. P2 group showed mammary gland proliferation, epithelial cell hyperplasia into 1-3 layers, necrotic cells, polymorphonuclear cells (PMN), dense fibroblast cell proliferation, and lowering number of adipose cells for being taken over by fibroblast cells. Meanwhile, in group P3, P4, and P5, glands epithelial underwent apoptosis, a small number of gland epithelial in 1-2 layers, and PMN, fibroblast, and adipose cells in moderate number. P6 and P7 features showed a lot of one-layer epithelial glands, few apoptotic epithelial cells, and few PMN and fibroblast proliferation. The microscopic feature showed that CLEE administration can inhibit inflammation, curatively cause tumor cell reduction and preventively inhibit tumor cell growth compared to the $\mathrm{P} 2$ group. This process is presumably caused by the alkaloid, flavonoid, and phenol compound contained in curry leaf extract which acts as anticancer and anti-inflammation. 

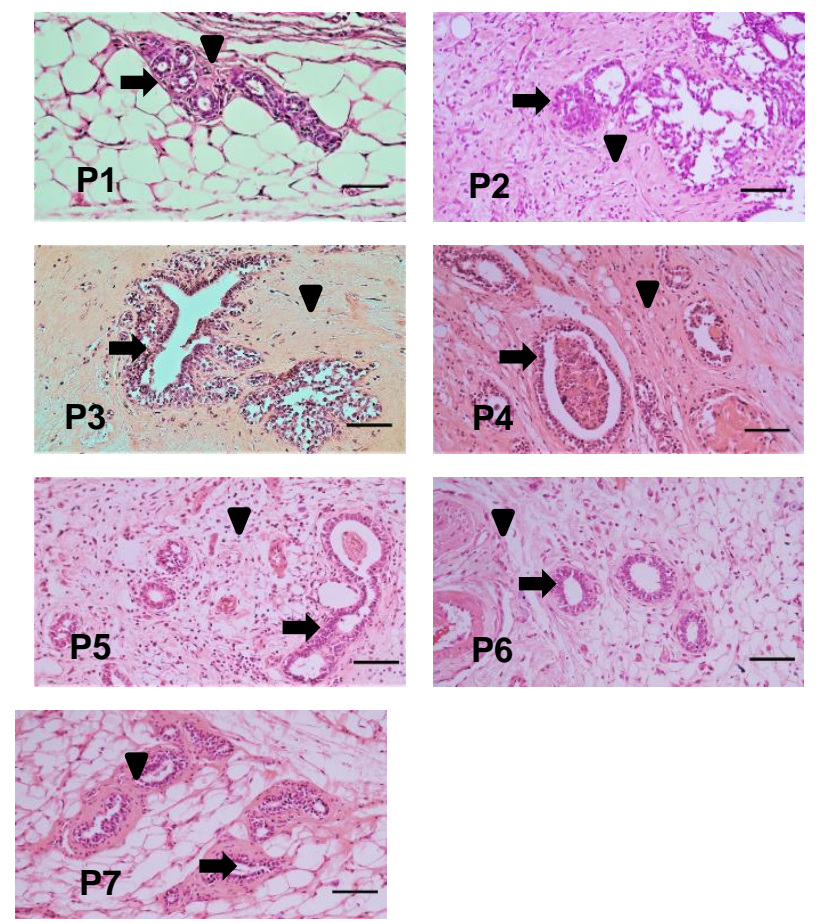

Figure 3. Rat mammary glands histology and histopathology. Mammary gland epithelial cell (arrow) and collagen fiber (arrowhead). Histology of P1 normal group. P2 Mammary tumor. P3 Methotrexate. P4 Curative with CLEE $300 \mathrm{mg} / \mathrm{kg}$. P5 Curative with CLEE $400 \mathrm{mg} / \mathrm{kg}$. P6 Preventive with CLEE $300 \mathrm{mg} / \mathrm{kg}$. P7 Preventive with CLEE $400 \mathrm{mg} / \mathrm{kg}$. Magnification 200x.

Research result obtained by several researchers in invitro and in vivo experiments showed that curry leaf extract has anti-inflammation, cytotoxic, and cell cancer apoptotic potential. [11] stated that fresh curry leaf extract can have chemo-preventive nature by lowering the percentage of cancer-positive mice. Curry leaf extract has the potential as anti-inflammation with an inflammatory inhibitory activity percentage of $57.42-60 \%$ and can inhibit tumor cell proliferation [13]. Research by [15] showed that curry leaf extract has a chemo-preventive ability on BALB/c mice by showing inflammatory and immunomodulatory effect which increases immunity, postponing the creation of mammary cancer and caused cytotoxicity. [6], alkaloid compound girinimbine contained in curry leaf can induce apoptosis in zebrafish embryo and mice with peritonitis. This compound can limit the migration of neutrophil cells and decrease the level of proinflammatory cytokine.

This research showed that the administration of CLEE for 30 days can slow the growth of mammary tumors. CLEE effect is almost similar to other herbal medicine in mammary tumor therapy, as stated in the following researches: Andrographis paniculata administration in SD rats can lower mammary cancer growth [16]. [17] stated that soursop leaf extract for 30 days in $\mathrm{C} 3 \mathrm{H}$ mice can lower the growth of the mammary tumor. [18] reported that the use of Carica papaya leaf can prevent mammary tumor growth in Wistar rats.

\section{Conclusion}

CLEE administration in the preventive and curative group in 300 and $400 \mathrm{mg} / \mathrm{kg}$ dosage can lower inflammation, inhibit cancer cell proliferation that tumor size appeared smaller than the tumor control group. The best CLEE dosage for therapy is $300 \mathrm{mg} / \mathrm{kg}$. Based on this research's result it can be concluded that curry leaf has the potency to be mammary anti-cancer.

\section{References}

1. [DEPKES] Departemen Kesehatan: Pusat Data Dan Informasi (Infodatin-Kanker). Kementerian Kesehatan RI. Jakarta Indonesia. 2015.

2. Memon M, Shah AA, Khan AZ, et al.: Careful surgery, management, and treatment of Feline (cat) breast cancer. Journal of Animal Research and Nutrition. 2016; 1(2): 1-4.

3. Kintzios SE, Barberaki MG: Plants and Cancer. In : Kintzios SE, Barberaki MG (eds) Plants That Fight Cancer. CRC Press. New York. 2004; 15-32.

4. Noolu B, Ajumeera R, Chauhan A, et al.: Murraya koenigii leaf extract inhibits proteasome activity and induces cell death in breast cancer line. $B M C$ Complementary \& Alternative Medicine. 2013; 13 (7) : 1 $-17$.

5. Ghasemzadeh A, Hawa Z, Jaafar F, et al.: Evaluation of bioactive compouns, pharmaceutical quality, and anticancer activity of curry leaf (murraya koenigii $\mathrm{L}$ ). Evidence-Based Complementary and Alternative Medicine. 2014; $1-8$.

6. Iman V, Mohan S, Abdelwahab SI, et al.: Anticancer and anti-inflammatory activities of girinimbine isolated from Murraya koenigii. Drug Design, Development and Therapy. 2017; 11: 103-121

7. Arun A, Patel OPS, Saini D, et al.: Anti-colon cancer activity of Murraya koenigii leaves is due to constituent murrayazoline and omethylmurrayamine a induced mTOR/AKT downregulation and mitochondrial apoptosis. Biomedicine \& Pharmacotherapy. 2017; 93:510-521.

8. Abbasalipourkabir R, Dehghan A, Salehzadeh A, et al.: Induction of mammary gland tumor in female Sprague dawley rats with LA7 cells. African Journal of Biotechnology. 2010; 9(28):4491-4498.

9. Sakarkar DM, Tembhume SV, More BH: 28 Days repeated dose toxicity study of ethanolic extract of Murraya koenigii in Wistar rats. Annals of Pharmacology and Pharmaceutics. 2017; Vol 2(8): 1047.

10. Saini SC, Reddy GBS: Acute toxicity study of Murraya koenigii. JPSI . $2012 ; 2$ : 34-36.

11. Dasgupta T, Rao AR, Yadava PK: Chemomodulatory action aof curry leaf (murayya koenigii) exract on hepatic and extrahepatic xenobiotic metabolising enzymes, antioxidant levels, lipid, peroxidation, skin and forestomach papillomagenesis. Nutrition Research. 2003; 23: 1427 - 1446.

12. Patel NN, Ghodasara DJ, Pandey S, et al.: Subacuta toxicopathological studies of methotrexate in wistar rats. Vet World, EISSN. 2014; 2231-0916.

13. Muthumani $\mathrm{P}$, Venkatraman $\mathrm{S}$, Ramseshu $\mathrm{KV}$, et al.: Pharmacological studies of anticancer, anti inflammatory activities of murraya koenigii (Linn) Spreng in experimental animals. J Pharm Sci and Res. $2009 ; 1$ (3) : $137-141$. 
14. Ismail A, Noolu B: Murraya koenigii leaves: a poten anti-cancer agent against breast cancer. $J$ Cancer $S c i$ Ther. 2015; 7:10

15. Yeap SK, Abu N, Mohamad NE, et al.: Chemopreventive and immunomodulatory effects of murraya koenigii aqueous extract on 4T1 breast cancer cell-challenged mice. BMC Complementary \& Alternative Medicine. 2015; 15 (306) : 1-10.

16. Sastyarina Y, Khotib J, Sukardiman: Efek ekstrak sambiloto (andrographis paniculata nees) pada ekspresi P53 dari kanker mammae tikus yang diinduksi DMBA. J Trop Pharm Chem. 2011; 1(2): 168176
17. Hussaana A, Djam'an Q, Goenarwo, et al.: Ekstrak daun sirsak (Annoma muricata) sebagai penghambat perkembangan tumor payudara. Journal of Pharmaceutical Science and Pharmacy Practice. 2015; 2: 41-44.

18. Gurudatta M, Deshmukh YA, Naikwadi AA: Anticancer effects of Carica papaya in experimental induced mammary tumors in rats. Int $J$ Med Res Health Sci. 2015;4(3):667-671. 